\title{
Evaluation of organochlorine pesticide residues and fipronil in Corumbataí river basin, Piracicaba, São Paulo, Brazil
}

\author{
Ana Lucia Cella ${ }^{1}$, Graziela C. R. Moura-Andrade* ${ }^{1}$, \\ Rosana M. O. Freguglia ${ }^{1}$, Valdemar Luiz Tornisielo ${ }^{1}$ \\ ${ }^{1}$ (Laboratory of Ecotoxicology, Center of Nuclear Energy in Agriculture, \\ University of São Paulo. Av. Centenário, 303 CEP: 13416-903, Piracicaba, São Paulo, Brazil.)
}

\begin{abstract}
The basin of the Corumbatai despite their considerable state of preservation, as regards quantity and quality of water, deserves special attention since provide $100 \%$ of supply in the city of Piracicaba, SP and other municipalities. Furthermore, in these cities it's expressive the intensive use of land for sugar cane cultivation, where it is used, among other inputs, the pesticide fipronil. Despite the great importance of the basin for the region, there are few studies that demonstrate the impact of agriculture and intensive use of pesticides in water quality. Thus this study has as objective of the environmental monitoring in the basin of the Corumbatai, determining the occurrence of residues of the pesticides fipronil and a group of organochlorines (OCPs), which are: alachlor, chlordane, endosulfan, heptachlor and heptachlor epoxide, lindane, metolachlor and methoxychlor in waters from differents collection points, and validate the methodology for extraction and analysis by gas chromatography (GC-MS). The samples analyzed (40) presented levels of OCPs and fipronil lower than allowed by Brazilian legislation.
\end{abstract}

Keywords-Corumbataí river basin, fipronil, GC-MS, organochlorines, pesticides

\section{INTRODUCTION}

Several hundred pesticides of different chemical nature are currently used for agricultural purposes all over the world. Because of their widespread use, they are detected by determination of their residues in various environmental matrices, such as soil, water and air. Pesticides are divided into many classes, of which the most important are organochlorine and organophosphorous compounds. Organochlorine pesticides (OCPs) are known to resist biodegradation and therefore they can be recycled through food chains and to produce a significant magnification of the original concentration at the end of the chain. Pesticide residues reach the aquatic environment through direct run-off, leaching, careless disposal of empty containers, equipment washings etc[1, $2,3,4]$.

Due to the long residence time of OCPs in the environment, there is still a great interest in examining the pollution they cause [5,6]. Their use has been prohibited in Brazil as well as in other countries, after evidence of their toxicity, persistence and bioaccumulation in the environment became available. The most OCPs have not been allowed for use in agriculture since 1985, although still use is allowed under specific conditions. In the culture of sugar cane the allowed Maximum Residue Level for the endosulfan is 0.01 (sum) and $0.1 \mathrm{mg} \cdot \mathrm{kg}^{-1}$ for alachlor.

Fipronil has been widely used in sugar-cane crops to control lepidoptera and orthoptera on crops and coleoptera larvae in soils. The rise in fipronil consumption may be due to its effectiveness against insects that are resistant to pyrethroids, organophosphate and carbamate insecticides. After reaching the environment, this insecticide may have several fates as water, soil and biota [7].

The Corumbatai river sub-basin is of great socioeconomic importance for the state of São Paulo, which the river of the same name, became the target of greater concern in recent years, when started to attend $100 \%$ of water supply in the city of Piracicaba, SP. The surrounding area is mainly exploited by the culture of sugar cane and is composed of soils with different physicochemical characteristics and soil varying from flat to hilly. There is widespread concern about the environmental behavior of pesticides employed in this basin [8].

The Corumbataí river basin is located in the central-western of the state of São Paulo, between parallels $22^{\circ} 04^{\prime} 46^{\prime \prime} \mathrm{S}$ and $22^{\circ} 41^{\prime} 28^{\prime \prime} \mathrm{S}$ and meridians $47^{\circ} 26^{\prime} 23^{\prime \prime} \mathrm{W}$ and $47^{\circ} 56^{\prime} 15^{\prime \prime} \mathrm{W}$, is approximately 170.000 ha, being that most section of its area is in the Peripheral Depression Paulista. It is divided into the following sub basins: Alto Corumbataí (31801.68 ha), Passa-Cinco (52757.60 ha), Médio Corumbataí (29316.60 ha), Ribeirão Claro (28174.90 ha) and Baixo Corumbataí (28724.84 ha) [9]. 
To study the fate and transport of pesticides in natural waters, very low detection limits must be reached. The trace determination of pesticides requires both high performance analytical instruments and efficient sample preparation. Analysis of natural waters for pesticides is recognized as complex, since several hundred pesticides with different physical and chemical properties are widely used for agricultural purposes. Analysis is also considered difficult and prone to errors due to the very low concentrations of the compounds [10].

The Environmental Company of São Paulo - CETESB is the agency of the State Government responsible for the control and supervision of the water quality in the Corumbataí river basin, which performs water sampling and analysis. According to the annual report released by the company in 2011 [11], among the various parameters analyzed in the water, pesticide residues analyzes are not executed. According to the environmental Legislation [12] establishing the conditions for a surface water is determined the monitoring of organic compounds of different chemical classes, especially organochlorines, most of which have prohibited use since 1985.

Some studies have been developed in the Corumbataí river sub-basin evaluating, for example, the biogeodynamics of pesticides used in cultivation of sugar cane, metals in sediments and suspended materials, water quality index (WQI) and chemicals in water and sediment, providing a improved knowledge and monitoring of this important source of water for the region $[8,13,14]$.

The determination of pesticide residues in water samples is necessary to helping for solving various environmental and biological problems. This paper describes the determination of the alachlor, chlordane, endosulfan, heptachlor and heptachlor epoxide, lindane, metolachlor, methoxychlor and fipronil from the study conducted in Corumbataí basin of state of São Paulo, Brazil for a period from November 2006 to June 2007. The objective is to provide an summary of the concentrations and frequencies of detection of OCPs and fipronil in surfacewaters, by gas chromatography, utilizing two different methods of extraction.

\section{MATERIALS AND METHODS}

\subsection{Characterization of the study area}

The Corumbataí river sub-basin (Fig. 1) is located in the central-eastern of the state of São Paulo, having most of their lands in the Peripheral Depression Paulista, includes the cities of: Analândia, Corumbataí, Ipeúna, Itirapina, Santa Gertrudes, Rio Claro, Charqueada and Piracicaba [14].

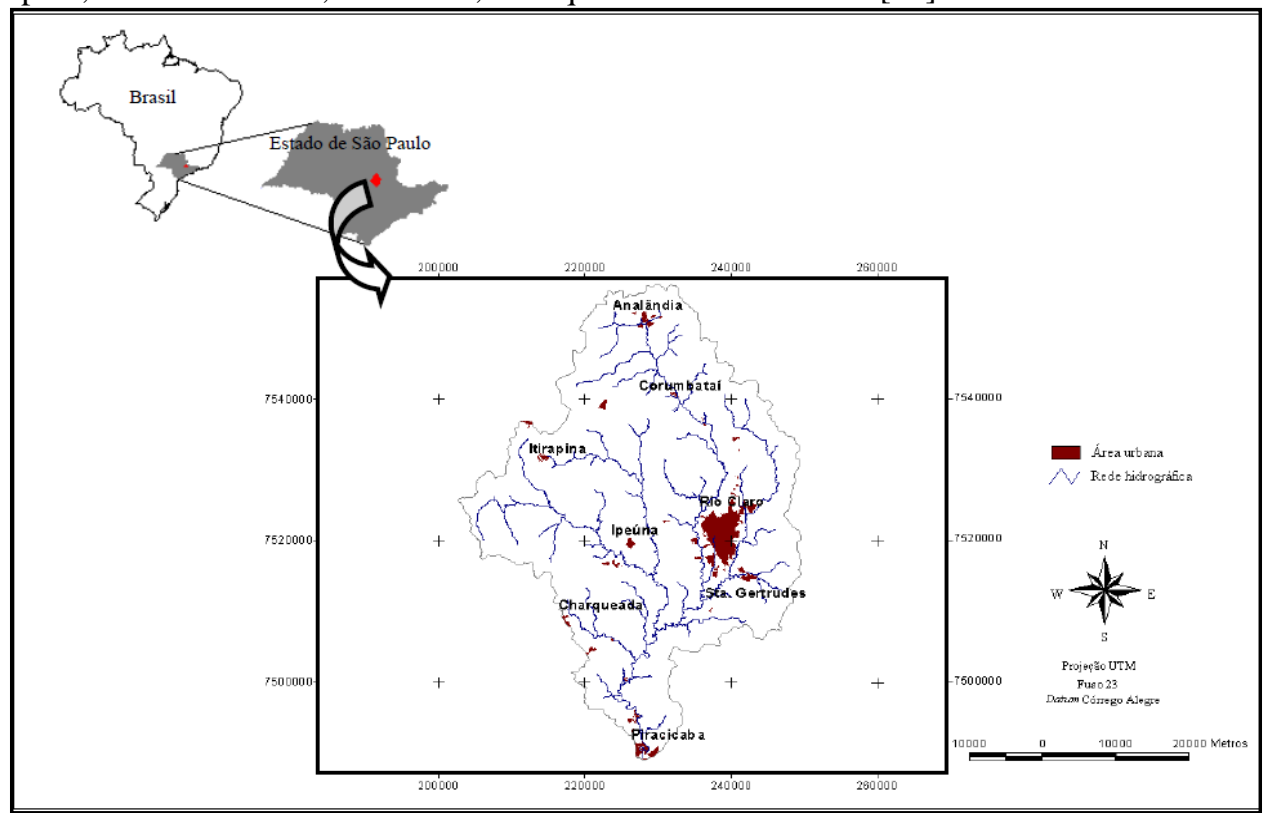

Figure 1. Location map of the Corumbatai river sub-basin (adapted from Instituto de Pesquisas e Estudos Florestais [15])

\subsection{Sampling}

For pesticide analysis it was established four collection points and monitoring of water in the basin and during the collections was measured the following water quality parameters: temperature, dissolved oxygen, turbidity, conductivity, $\mathrm{pH}$, which were determined by using a multiparameter probe Horiba ${ }^{\circledR}$.

Samples were collected during 8 (eight) months in order to achieve a result of the seasonal profile of this region, and the collection and preservation of samples were performed according to ABNT [16]. The frequency of collection points was collected monthly with the exception of point 1 , which was quarterly. After transportation to the laboratory, samples were stored at $-20^{\circ} \mathrm{C}$ and extraction was normally done within 7 days. 


\subsection{Chemicals and instrumentation}

The solvents used for the extraction hexane, isopropanol, methanol and acetone were obtained from Merck (LC grade). The standards for the pesticides chosen for the study were obtained from Accustandart@. Ultrapure water used to prepare spiked samples and as a solvent for SPE extraction was obtained from a Milli-Q system (Millipore, Molsheim, France)

Analyses were conducted in laboratorie of Bioagri Environmental Ltda in partnership with Centre for Nuclear Energy in Agriculture - CENA / USP - Laboratory of Ecotoxicology.

\subsection{Chromatographic analysis}

The pesticide residues were analyzed by gas chromatography (GC) using a Agilent Model $6890 \mathrm{~N}$ and quadrupole mass spectrometer Agilent Model 5973N. A capillary column Varian CP-Sil 8CB $35 \mathrm{~m} \mathrm{x} 0.25 \mathrm{~mm}$ x $0.25 \mu \mathrm{m}$ film thickness fused silica was used for the chromatographic separation of fipronil and Supelco SPB-35 $30 \mathrm{~m} \times 0.25 \mathrm{~mm} \times 0.25 \mu \mathrm{m}$ was used for the chromatographic separation of OCPs. Nitrogen was used as the carrier gas and the injection technique was in the splitless mode.The GC conditions used are presented in Table 1.

Table 1.GC-MS conditions

\begin{tabular}{lll}
\hline Condition & $\mathrm{SPE}$ & Liquid-liquid extraction \\
\hline GC-Injection volume & $2 \mu \mathrm{L}$ & $2 \mu \mathrm{L}$ \\
GC-Injector pressure & $12.53 \mathrm{psi}$ & $24.7 \mathrm{psi}$ \\
GC-Injector temperature & $250^{\circ} \mathrm{C}$ & $250^{\circ} \mathrm{C}$ \\
GC-purge flow & $200 \mathrm{~mL} / \mathrm{min}$ & $205 \mathrm{~mL} / \mathrm{min}$ \\
GC-Oven programming & $100^{\circ} \mathrm{C}$ for $2 \mathrm{~min} ;$ & $60^{\circ} \mathrm{C}$ for $2 \mathrm{~min} ;$ \\
& $100-250^{\circ} \mathrm{C}$ at $25^{\circ} \mathrm{C} / \mathrm{min} ;$ & $60-220^{\circ} \mathrm{C}$ at $15^{\circ} \mathrm{C} / \mathrm{min} ;$ \\
& $250^{\circ} \mathrm{C}$ for $2 \mathrm{~min}$ & $220^{\circ} \mathrm{C}$ for $7 \mathrm{~min}$ \\
Total run time & & $220-300^{\circ} \mathrm{C}$ at $20^{\circ} \mathrm{C} / \mathrm{min}$ \\
GC-flow & $10 \mathrm{~min}$ & $23.67 \mathrm{~min}$ \\
MS- Transfer line temp. & $1 \mathrm{~mL} / \mathrm{min}$ & $1 \mathrm{~mL} / \mathrm{min}$ \\
MS-Source temp. & $300^{\circ} \mathrm{C}$ & $300^{\circ} \mathrm{C}$ \\
\hline
\end{tabular}

\subsection{Analytical procedure}

Solid Phase extraction followed by gas chromatographic detection [17] was used for the determination

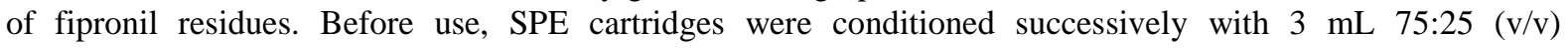
hexane:isopropanol, $500 \mu \mathrm{L}$ methanol and $1 \mathrm{~mL}$ of MilliQ-water. Water samples $(500 \mathrm{~mL})$ were loaded under vacuum at a flow rate of $10 \mathrm{~mL} \mathrm{~min}^{-1}$. After sample loading, cartridges were dried under vacuum for $20 \mathrm{~min}$. After elution with $6 \mathrm{~mL}$ 75:25 (v/v) hexane:isopropanol the collected extracts were evaporated to dryness under a gentle stream of nitrogen and redissolved in $1000 \mu \mathrm{L}$ acetone.

Liquid-liquid extraction followed by gas chromatographic detection [18] was used for the determination of OCPs residues. 11 of the water sample was extracted by adding $60 \mathrm{~mL}$ of dichloromethane (three times with $20 \mathrm{~mL}$ ) and shaking vigorously for 2 minutes. The extracts were combined and dried with anhydrous sodium sulfate. The process was repeated with more $60 \mathrm{~mL}$ of dichloromethane. The resulting extract was concentrated to exactly $2 \mathrm{~mL}$ using a rotary evaporator (Buchi R-215) and gentle nitrogen stream to 100 $\mu \mathrm{L}$. Then, GC/MS analysis was performed as described in Section 2.4.

The mass spectrum of each compound was characterized in full-scan mode and selected-ion-monitoring mode was used for all quantitative measurements. Retention times, $\mathrm{m} / \mathrm{z}$ ratios, and limits of detection used for quantitative purposes are given in Table 2. The limit of detection (LoD) for these compounds derived by use of a signal-to- noise ratio 1:3. Blanks were performed for each batch experiment to monitor possible contamination. No compounds were found in blank samples. 
Evaluation of organochlorine pesticide residues and fipronil in Corumbataí river basin...

Table 2. Retention times, $\mathrm{m} / \mathrm{z}$ ratios, and limits of detection of OCPs and fipronil by gas Chromatography

\begin{tabular}{llll}
\hline Pesticide & Retention times $(\mathrm{min})$ & $\mathrm{m} / \mathrm{z}$ ratios & $\mathrm{LoD}\left(\mu \mathrm{g} . \mathrm{L}^{-1}\right)$ \\
\hline fipronil & 8.9 & $369-367-213$ & 0.03 \\
heptachlor & 16.74 & $272-100-274$ & 0.01 \\
heptachlor epoxide & 17.76 & $353-355-350$ & 0.01 \\
lindane & 15.73 & $183-181-184$ & 0.005 \\
endosulfan & 19.02 & $241-243-238$ & 0.01 \\
alachlor & 16.55 & $160-188-146$ & 0.004 \\
chlordane & 18.06 & $375-373-376$ & 0.01 \\
metolachlor & 17.08 & $162-238-163$ & 0.002 \\
methoxychlor & 20.12 & $228-212-114$ & 0.003 \\
\hline
\end{tabular}

The recommended surrogates p-terphenyl-d14 and 2-fluorobiphenyl [19] was used for to monitor method performance with each sample concentration and extraction steps. Were added in a concentration of 250 $\mu \mathrm{g} . \mathrm{L}^{-1}$ in water samples extracted by SPE and 1.0 and $5.0 \mu \mathrm{g} . \mathrm{L}^{-1}$ in the samples prepared by liquid-liquid extraction.

\section{RESULTS AND DISCUSSION}

The correlation coefficient ( $\mathrm{r} 2$ ) for each pesticide was more than 0.9961 for the selected range. The limit of detection (LOD) was set as the lowest concentration with a signal-to-noise ratio (S/N) of at least 3 , while the limit of quantification (LOQ) was 10 times S/N. The LOQs ranged from 0.03 to $0.1 \mu \mathrm{g} . \mathrm{L}^{-1}$ and were adequate for the monitoring of the compounds studied in accordance with determined values by CONAMA [12]. Recoveries at low $\left(0.1 \mathrm{mg} . \mathrm{L}^{-1}\right)$, medium $\left(0.5 \mathrm{mg} \cdot \mathrm{L}^{-1}\right)$ and high $\left(1 \mathrm{mg} . \mathrm{L}^{-1}\right)$ levels ranged between $108 \%$ and $123 \%$, the RSD was between $1 \%$ and $5 \%$.

Only limited data was available on contamination of pesticides in Corumbataí basin (Armas,2007; Armas 2005). This study revealed that the OCPs and fipronil contamination in surfacewater samples was below the allowed values in CONAMA (Table 3). The sediment has been increasingly used in studies to assess the quality of aquatic ecosystems, because it represents the historical conditions of the influence of human activities on these environments, not always detectable by the use of water variables. The interaction between sediment and water column can be a source of contamination and interaction can occur through the revolving of the sediment, for example, because of increased flow due to rainfall or activities affecting the bed of the river as dredging operations, pipeline crossing, construction of support columns of bridges among others [11].

Table 3. Results of quantification of the compounds analyzed in the four points of the study

\begin{tabular}{|c|c|c|c|c|c|}
\hline \multirow{2}{*}{ Pesticide } & \multicolumn{3}{|c|}{ Points $\left(\mu \mathrm{g} . \mathrm{L}^{-1}\right)$} & \multirow[b]{2}{*}{4} & \multirow{2}{*}{$\begin{array}{c}\text { MPV Conama } 357 \\
\left(\mu \mathrm{g} . \mathrm{L}^{-1}\right)\end{array}$} \\
\hline & 1 & 2 & 3 & & \\
\hline fipronil & $<0.2$ & $<0.2$ & $<0.2$ & $<0.2$ & (ND) \\
\hline alachlor & $<1$ & $<1$ & $<1$ & $<1$ & 20 \\
\hline chlordane & $<0.02$ & $<0.02$ & $<0.02$ & $<0.02$ & 0.04 \\
\hline endosulfan & $<0.03$ & $<0.03$ & $<0.03$ & $<0.03$ & 0.056 \\
\hline heptachlor + heptachlor epoxide & $<0.01$ & $<0.01$ & $<0.01$ & $<0.01$ & 0.01 \\
\hline lindane & $<0.01$ & $<0.01$ & $<0.01$ & $<0.01$ & 0.02 \\
\hline metolachlor & $<1$ & $<1$ & $<1$ & $<1$ & 10 \\
\hline methoxychlor & $<0.01$ & $<0.01$ & $<0.01$ & $<0.01$ & 0.03 \\
\hline
\end{tabular}

M.P.V. maximum permissible values

(ND) not determined 
It is well known that most of the applied pesticides are subject to many transport and conversion products. Thus, they do not remain at their target site but often enter in a aquatic environment via soil leaching, air drift or surface runoff affecting abundance and diversity of non-target species producing complex effects on the ecosystems and altering tropic interactions [20]. In addition, many pesticides eventually end up in ground water and their transformation products may remain for years [21].

From large-scale studies that monitored herbicide losses to surfacewater it can be concluded that, on average, less than $2 \%$ of the total mass applied within large catchments is ultimately lost to surfacewaters and that losses occur primarily during and right after the application period [22]. Furthermore, such studies show that weather conditions, soil type, land use, intrinsic properties of the compound, as well as point sources are crucial factors influencing the overall herbicide loss from a watershed [22,23].

The monitoring of pesticide residues in water bodies, in hydrographic basins, is an onerous task and low success in the real estimate of the risks associated with its use, since their occurrence in water bodies is observed in peaks, and these are associated the application and rainfall and pedological factors favorable to its displacement, which are temporally heterogeneous in the basin. This reduces the probability of obtaining samples in a certain time and to assess risk and identify critical areas of the basin under study [14].

There are no records in the Brazilian legislation on acceptable limits of residues of fipronil in water bodies, in this case the work was based on international studies, among them Hamilton et al., 2003 [24], which established a limit of $0.5 \mu \mathrm{g} \mathrm{L}^{-1}$ for residues of fipronil in water used for irrigated rice.

Due to its very low vapor pressure and Henry.s Law constant, fipronil is not likely to be found in the air. Fipronil is readily transformed into its desulfinyl photodegradate when exposed to sunlight. This photoproduct has a high affinity for insect GABA regulated chloride channels. Consequently, the photoproduct is neurotoxic toward insects. Datas indicate that fipronil is much more susceptible to breakdown through photolysis rather than hydrolysis in water. Under environmental $\mathrm{pH}$ fipronil is stable to hydrolysis with a halflife of 1390 days at $\mathrm{pH} 7.1\left(22^{\circ} \mathrm{C}\right)$. The laboratory photolytic halflife was 4.1 hours; suggesting that photolysis is a more important pathway for the degradation of aqueous fipronil [25]. In metabolic studies it is observed that there is a potential to bioaccumulate in fatty tissues of the desulfinyl [26].

According Rayton et al., 2006 [27] fipronil degrades slowly in water and sediments in anaerobic conditions, with half-life between 116 and 130 days. The residues tend to remain in the upper layer of soil and exhibit low potential for the leaching water depth, and in aquatic environments, fipronil residues water quickly move to sediment.

\section{CONCLUSION}

In this study the level of OCPs and fipronil in water was investigated using two extraction methods by GC-MS. Results showed that the levels of OCPs detected and fipronil were lower than the regulatory level. Overall, the health risk associated with exposure to pesticides via water consumption was negligible. This sort of study is useful to evaluate the effectiveness of legislative actions on the input of contaminants in the environment. However, little research has been done on Brazilian watersheds.

Although not detected the presence of contaminants in the monitoring punctual, the damage to the water quality of Corumbataí is mainly due to the increase of urban runoff and increasing industrial, extractive and agricultural surroundings.

\section{ACKNOWLEDGEMENTS}

To FAPESP (Fundação de Amparo à Pesquisa do Estado de São Paulo) and CNPq (Conselho Nacional de Desenvolvimento Científico e Tecnológico) for financial support.

\section{REFERENCES}

[1]. E.A. Laws, Aquatic pollution: an introductory text (New York, John Willey and Sons, 2000).

[2]. S.K. Golfinopoulos, A.D. Nikolaou, M.N. Kostopoulou, N.K. Xilourgidis, M.C. Vagi, and D.T Lekkas, Organochlorine pesticides in the surfacewaters of Northern Greece, Chemosphere, 50(4), 2003, 507-516.

[3]. O.M. Baldino, E.A. Suero, M. Augusto, M.E. Gimenez., and N. Flores, Monitoring organochlorine pesticides in surface and ground water in San Juan Argentina, Journal of the Chilean Chemical Society, 48(2), 2003.

[4]. Y.F. Guan, J.Z. Wang, H.G. Ni, and E.Y. Zeng, Organochlorine pesticides and polychlorinated biphenyls in riverine runoff of the Pearl River Delta, China: Assessment of mass loading, input source and environmental fate, Environmental Pollution ,157(2), 2009, 618-624.

[5]. D.M.L. Silva, P. B. Camargo, L.A. Martinelli, F.M. Lanças, J.S.S. Pinto, and W.E.P. Avelar, Organochlorine pesticides in Piracicaba river basin (São Paulo/Brazil): a survey of sediment, bivalve and fish, Química Nova, 31(2), 2008, 214-219.

[6]. E.M.S. Brito, E.D.R. Vieira, J.P.M. Torres, and O. Malm, Persistent organic pollutants in two reservoirs along the Paraíba do Sul-Guandu river system, Rio de Janeiro, Brazil, Química Nova, 28(6), 2005, 941-946. 
[7]. A.M. Peret, L.F. Oliveira, I. Bianchini Jr, M.H.R. Seleghim, A.C. Peret, and A.A. Mozeto, Dynamics of fipronil in Óleo Lagoon in Jataí Ecological Station, São Paulo-Brazil, Chemosphere, 78(10), 2010, 1225-1229.

[8]. E.D. Armas, R.T.R. Monteiro, P.M. Antunes, M.A.P.F. Santos, P.B. Camargo, and R. B. Abakerli, Spatialtemporal diagnostic of herbicide occurrence in surface waters and sediments of Corumbataí River and main affluents, Química Nova, 30(5), 2007, 1119-1127.

[9]. R.O.A. Valente, and C. A. Vettorazzi, Landscape structure analysis of the Corumbataí River Basin, SP, Scientia Forestalis, 62, 2002, 114-129.

[10]. L. Alder, K. Greulich, G. Kempe, and B. Vieth, Residue analysis of 500 high priority pesticides: better by GC-MS or LC-MS / MS ?, Mass Spectrometry Reviews, 25(6), 2006, 838-865.

[11]. Cetesb, Relatório de Qualidade das Águas Superficiais do Estado de São Paulo, <http://www.cetesb.sp.gov.br/agua/aguas-superficiais/35-publicacoes-/-relatorios>, 2011.

[12]. Brasil. Conselho Nacional de Meio Ambiente. Resolução $\mathrm{n}^{\circ}$ 357, de 17 de março de 2005, < http://www.mma.gov.br/port/conama/res /res05/res35705.pdf>.

[13]. D.M. Bonotto, and J.L.N. Lima, Hydrochemistry and weathering rates on Corumbataí River basin, São Paulo State, Brazil, Journal of Hydrology, 383(3-4), 2010, 291-306.

[14]. E.D. Armas, and R.T.R. Monteiro, The use of pesticides in sugar cane at the Corumbataí river basin and the risk of water pollution, Química Nova, 28(6), 2005, 975-982.

[15]. Instituto de Pesquisas e Estudos Florestais, <http://www.ipef.br/publicacoes/scientia/nr68/cap05.pdf>, 2005.

[16]. Associação Brasileira de Normas Técnicas - ABNT. Norma ABNT NBR 9898 - Preservação e técnicas de amostragem de efluentes líquidos e corpos receptores, 1987.

[17]. D. S. Zaugg, M. W. Sandstrom, and S. G. Smith, Methods of analysis by the U.S. geological survey national water quality laboratory - A method supplement for the determination of fipronil and degradates in water by gas chromatography/mass spectrometry, Denver, Colo.: U.S. Department of the Interior, U.S. Geological Survey, 1995. 49 p. Series U.S. Geological Survey Report, 95-181.

[18]. USEPA. New pesticide fact sheet. PB96- 181516. EPA737-F-96-005. Washington: Office of Prevention, Pesticides and Toxic Substances, 1996, 1-10.

[19]. Environmental Protection Agency - Method 8270C - Semivolatile Organic Compounds by Gas Chromatography Mass Spectrometry (GC/MS) - Revision 3 - December 1996.

[20]. G.M. Rand, P.G. Wells, and L.S. Mclarty, Introduction to aquatic toxicology (Washington, Taylor and Francis, 1995).

[21]. A.C. Belfroid, M .Van Drumen, M.A. Beck, S.M. Schrap, C.A.M. Van Gestel, and B. Van Hattun, Relative risks of transformation products of pesticides for aquatic ecosystems, Science of the Total Environment, 222(3), 1998, $167-183$.

[22]. P.D. Capel, S.J. Larson, and T.A. Winterstein, The behavior of thirty-nine pesticides in surface waters as a function of scale, Hydrological Processes 15(7), 2001, 1251-1269.

[23]. J. Kreuger, 1998. Pesticides in stream water within an agricultural catchment in southern Sweden, 1990-1996, Science of the Total Environment. 216(3), 227-251.

[24]. D.J. Hamilton, A. Ambrus, R.M. Dieterle, A.S. Felsot, C. A. Harris, P. T. Holland, A. Katayama, N. Kurihara, J. Linders, J. Unsworth, and S.S. Wong, Regulatory limits for pesticide residues in water, Pure and Applied Chemistry, 75(8), 2003, 1123-1155.

[25]. P. Connelly, Environmental fate of fipronil, Environmental, California Environmental Protection Agency, 2001, $17 \mathrm{p}$.

[26]. D.K. Demcheck, and S.C. Skrobialowski, Fipronil and degradation products in the rice-producing areas of the Mermentau River Basin, Louisiana, February-September 2000. Washington: US Geological Survey, National Water-Quality Assessment Program, 2003.

[27]. M. Raveton, A. Aajoud, J.C. Willison, H. Aouadi, M. Tissut, and P. Ravanel, Phototransformation of insecticide fipronil: Identification of novel photoproducts and evidence for an alternative pathway of photodegradation, Environmental Science and Technology, 40(13), 2006, 4151-4157. 